\title{
The acceptability of rat trap use over pesticides for rodent control in two poor urban communities in South Africa
}

\author{
Rifqah Roomaney ${ }^{1,2}$, Rodney Ehrlich ${ }^{1}$ and Hanna-Andrea Rother ${ }^{1 *}$
}

\begin{abstract}
Background: Rodent infestations are a public health problem in poor urban communities. The use of illegal street pesticides to control rodent infestations with resulting poisonings is an additional public health concern receiving limited attention in many developing countries, including South Africa.

Methods: Participants in a household intervention in two poor urban areas of Cape Town, South Africa, received two high quality rat traps. Reported in this article are the results of a follow-up survey conducted six months after distribution to assess community perceived acceptability of using rat traps instead of toxic pesticides $(N=175)$.

Results: Of the 175 respondents that were followed up, 88\% used the traps and only 35\% continued using pesticides after the intervention. The analysis identified perceived effectiveness of the traps (prevalence odds ratio 18.00, 95\% confidence interval 4.62 to 70.14 ), being male (prevalence odds ratio 8.86, 95\% confidence interval 1.73 to 45.19 ), and the willingness to buy traps from an informal market (prevalence odds ratio $17.75,95 \%$ confidence interval 4.22 to 74.57) as significantly associated with the acceptance of trap use.

Conclusions: Rat traps, when introduced to poor urban communities, are acceptable as an alternative to toxic pesticides for rodent control. Sustainability of trap use, however, needs to be researched, especially cost and cost-benefit.
\end{abstract}

Keywords: Rat traps, Illegal pesticides, Informal settlements, Acceptability, Rodent control

\section{Background}

Rodent infestations, associated diseases and control measures are a global public health concern receiving little attention and often left to individuals to manage. Rodent infestations predominantly affect the urban poor because conditions in poor communities promote rodent breeding, such as poor sanitation and drainage, open drains, uncollected solid waste, improper storage of food and overcrowding of homes $[1,2]$. The epidemiology of rodent-borne diseases links rodents with a number of diseases such as, plague, leptospirosis, Lassa Fever, salmonellosis, rat-bite fever, viral hemorrhagic fevers and murine typhus [3-5]. These diseases are transmitted through rodent bites, contamination of food with rodent urine or by rodents acting as vectors for other organisms such as fleas [2-7].

\footnotetext{
* Correspondence: andrea.rother@uct.ac.za

${ }^{1}$ School of Public Health and Family Medicine, University of Cape Town, Anzio Rd., Observatory, 7925, Cape Town, South Africa

Full list of author information is available at the end of the article
}

People commonly rely on pesticides (which includes rodenticides) to manage rodent infestations as they are perceived to be the most effective method of control [8]. In poor communities in South Africa, people frequently use 'illegal street pesticides' which often are hazardous pesticides meant predominantly for agricultural use but which are decanted into containers without labelling and sold for domestic use at informal markets [9]. These pesticides are cheap, easily available, and effective as they are toxic, but are not meant for nor registered for domestic pest control [10]. A commonly used street pesticide, aldicarb, is so toxic that a $60 \mathrm{mg}$ sachet could potentially kill six children that weigh under $10 \mathrm{~kg}$ [10]. The use of illegal pesticides such as aldicarb for rodent control has been linked to human poisonings in poor settings in South Africa, Brazil, Zimbabwe, the United States and Israel [2,10-17]. Other commonly used street pesticides in South Africa, such as chlorpyrifos and methamidophos, are banned in several countries because of the high number of related poisoning cases [10].

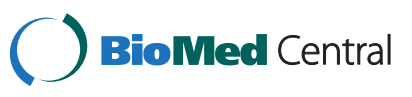


Unprotected exposures to pesticides can result in severe acute effects (such as fatal poisoning) and chronic health effects (such as birth defects, cancers, asthma, reproductive complications and neurological defects) [18-22]. Pesticide health effects studies are well documented from agricultural regions [23-27] and from urban areas [28-29]. The high risk of poisoning by rodenticides has been recognised as a public health concern by the United States Environmental Protection Agency (EPA). In 2011, the EPA issued a ban on the residential use of most toxic rat and mouse poisons because of the rash of accidental exposures to these substances [30]. In South Africa, similar action has not been taken even though there seems to be an increasing number of children treated for poisoning attributed to the intoxication of street pesticides $[9,10,19]$.

Non-toxic rodent control methods are needed in these at risk communities as there is an overuse of pesticides for rodent control [8]. There are, however, few studies which document people's attitudes towards using rat traps instead of pesticides. Studies in rural areas have indicated that rat traps are an acceptable alternative control method for rodents interfering in agricultural production [8,31]. No similar studies have been conducted for rodent problems in urban areas.

The use of non-toxic alternatives such as rat traps requires a shift in intentions for people to accept that these alternatives are as effective and feasible as pesticides. Several factors have been identified that are useful for understanding trap adoption and acceptability in poor communities, such as whether the traps are seen to be effective, whether they are easy to use, whether there is an additional benefit to using them and the extent of the rodent infestation [32-36].

This study aimed to investigate whether households in poor urban communities would use traps as a rodent control alternative and to identify factors influencing respondents' intention to switch from pesticides to rat traps. It was thus an acceptability study. Determining which factors influence the use of non-toxic rodent control has the potential to lower the use of pesticides, especially street pesticides, and reduce the risk of child poisoning and other risks.

\section{Methods}

This research formed part of a larger study that investigated the link between illegal street pesticides and child poisonings in two poor urban areas in Cape Town, South Africa [9,10]. The larger study identified the study sites, Philippi and Khayelitsha, as areas where numerous child poisonings had occurred due to street pesticides used for rodent control [9]. Both areas have high rat infestations as a result of poor sanitation, infrequent refuse removal and overcrowded living conditions [9]. Households were the units of sampling rather than individuals. The study was approved by the University of Cape Town's Human Research Ethics Committee.

\section{Study design}

The study design for this research was a cross-sectional survey. At the end of a baseline study, respondents were given an intervention (rat traps). A follow up survey was conducted six months later to assess the use of the rat traps and whether people intended to use traps and/or pesticides in the future (see Additional File 1). This article presents only the findings from the follow-up survey and compares respondents who said they would use rat traps in the future to those who said they would not.

A sample of two hundred households was selected, without a formal sample size calculation, as a practical sample size that would yield useful information. Systematic random sampling identified a house from every tenth house starting from the local community centre in each area. The household head or adult at home was interviewed after obtaining written consent. After participating in the baseline survey, each family received two free rat traps and instructions on how to set the traps, along with a demonstration from a fieldworker. The rat traps distributed had a higher spring action than conventional traps used in these communities which increased their effectiveness in rat catching (Figure 1). These traps are not usually available in outlets selling conventional rat traps.

Between March and May 2009, 200 face to face interviews were conducted by trained community fieldworkers in Philippi $(n=100)$ and Khayelitsha $(n=100)$. The same fieldworkers from the baseline survey were

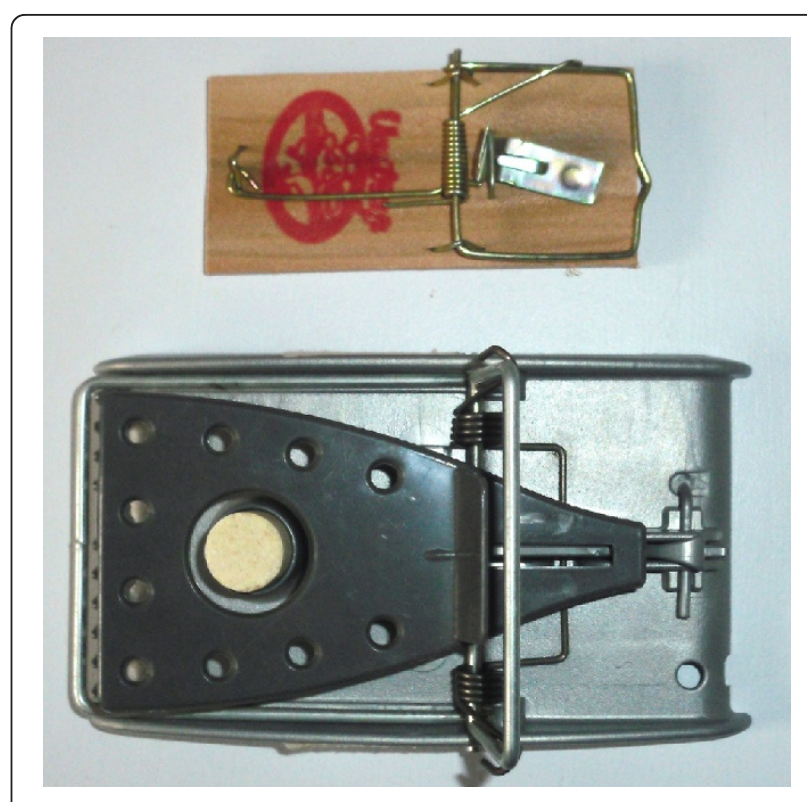

Figure 1 Example of commonly found rat traps (top) and rat traps distributed to respondents (bottom). 
employed six months later (November 2009) to administer the follow-up acceptability survey. The fieldworkers were given addresses to locate the selected houses. From these houses, it was possible to locate 175 of the households that had taken part in the baseline study. The loss to follow-up was due to one questionnaire being misplaced and some families having moved elsewhere. It was not required that the same respondent be followed up, only that they were from the same family that was given the rat trap.

\section{Analysis}

Reported intention to use rat traps in the future was analysed as the main dependent variable and was used as an indicator of acceptability of the rat traps. Reported intention to use pesticides in future was considered as the alternate outcome of interest. The factors related to the reported intended trap use considered were: 1) demographic data (age and sex), 2) whether the respondents reported using the traps, 3) the experienced effectiveness of the traps (whether the traps caught rodents and whether respondents reported any problems using the traps), 4) reported past and present pesticide use, 5) reported perceptions of the price of rat traps (if respondents believed rat traps to be more expensive than pesticides and whether they were willing to buy them) and 6) whether respondents reported still having a rodent problem. Open-ended questions were also asked about why the respondent did not use the rat traps (if such was the case) and what features the respondents liked about the rat traps.

Cross tabulations were used to identify factors related to the reported acceptability of rat trap use after the intervention. A codebook was developed for the qualitative responses and tabulated into themes corresponding to the variables. These were then categorised and converted into categorical data. Data analysis took place in the survey suite of STATA (STATA for Windows, version 10, Stata Corp; College Station, TX).

Multivariate logistic regression analyses were performed to assess the association between the independent and dependent variables. Thus reported "intended trap use" was the main outcome of interest, used to gauge whether respondents found the rat traps to be an acceptable alternative to pesticides. Results considered statistically significant were those with a two-tailed probability of 0.05 or less. To predict use and acceptability of traps, forward stepwise regression was carried out to obtain the predictive model with the best statistical fit which was determined by likelihood ratio tests.

\section{Results}

The median age of the follow-up sample was 31 years (range: 25 to 41 years), with a small female excess $(53.8 \%, \mathrm{n}=93)$. The median schooling grade attained was Grade 11 (range: Grade 8 to Grade 12). Monthly income levels were low - with the median category being US\$129.15 - US\$258.18 (range: US\$64.57 - US $\$ 129.05$ to US\$258.30 - 387.33US\$) (February 2012 exchange rate: US\$1.00 = ZAR7.74).

Most of the study respondents reported using the intervention traps $(88.0 \%, \mathrm{n}=154)$ (Table 1$)$. Most respondents who used the traps reported that they caught rodents (96.1\%, $n=148$ ), confirming their effectiveness. The variables "used trap" and "trap caught rodents" were highly collinear and thus "used trap" was left out of further analyses. Most respondents reported they would use rat traps in the future $(84.5 \%)$, compared to a third who reported they would continue using pesticides (29.2\%). Most respondents reported using pesticides before the trap intervention (78.3\%), with significantly fewer reporting using pesticides at the time of the follow-up survey (34.5\%). More than half of the baseline pesticide users (57.6\%) were not using pesticides at follow up. Several respondents (21.7\%) reported that they intended to use both pesticides and rat traps in the future (see Additional File 2).

Whether the traps had caught rodents was strongly associated with the reported intention to use traps in the future [prevalence odds ratio (POR) 18.0, 95\% confidence interval (CI) 4.6 to 70.1] (Table 2). The reported willingness to buy a rat trap from an informal market where street pesticides are commonly sold (e.g. taxi ranks) was

Table 1 Follow-up results describing respondents' intentions and attitudes $(\mathrm{N}=\mathbf{1 7 5})$

\begin{tabular}{|c|c|c|c|}
\hline Data & Variable & $\begin{array}{l}\text { Total } \\
\text { (n) }\end{array}$ & $\begin{array}{l}\text { Yes } \\
(\%)\end{array}$ \\
\hline \multirow[t]{2}{*}{$\begin{array}{l}\text { Dependent } \\
\text { variable }\end{array}$} & $\begin{array}{l}\text { Will you continue using rat } \\
\text { traps for rats or mice? }\end{array}$ & 174 & 84.5 \\
\hline & $\begin{array}{l}\text { Will you continue to use } \\
\text { pesticides (poison/chemicals) } \\
\text { bought at shops or taxi ranks } \\
\text { to kill rats or mice? }\end{array}$ & 161 & 29.2 \\
\hline \multirow[t]{8}{*}{$\begin{array}{l}\text { Predictor } \\
\text { Variables }\end{array}$} & $\begin{array}{l}\text { Have you used the rat traps } \\
\text { since they were given to } \\
\text { you? }\end{array}$ & 175 & 88.0 \\
\hline & $\begin{array}{l}\text { Did the traps catch any rats } \\
\text { or mice? }\end{array}$ & 174 & 85.1 \\
\hline & $\begin{array}{l}\text { Were you using pesticides to } \\
\text { kill rats or mice before you } \\
\text { got these rat traps? }\end{array}$ & 175 & 78.3 \\
\hline & $\begin{array}{l}\text { Are you still using pesticides } \\
\text { to kill rats or mice? }\end{array}$ & 171 & 34.5 \\
\hline & $\begin{array}{l}\text { Do think it is more expensive } \\
\text { to buy rat traps compared } \\
\text { to pesticides monthly? }\end{array}$ & 167 & 62.9 \\
\hline & $\begin{array}{l}\text { Are rats and mice still a } \\
\text { problem in your house? }\end{array}$ & 171 & 44.4 \\
\hline & $\begin{array}{l}\text { Would you buy a rat trap } \\
\text { from a taxi rank/informal } \\
\text { market? }\end{array}$ & 173 & 79.2 \\
\hline & $\begin{array}{l}\text { Did you have problems or } \\
\text { difficulties using the traps? }\end{array}$ & 174 & 10.9 \\
\hline
\end{tabular}


Table 2 Models describing intentions of rat trap use

\begin{tabular}{lll}
\hline Variable & $\begin{array}{l}\text { Full Model } \\
\text { POR }(95 \% \mathrm{Cl})\end{array}$ & $\begin{array}{l}\text { Stepwise Regression } \\
\text { Model POR }(\mathbf{9 5} \% \mathrm{Cl})\end{array}$ \\
\hline Traps caught rodents & $\mathbf{1 6 . 0 2}(\mathbf{3 . 1 4 - 8 1 . 6 2 )}$ & $\mathbf{1 8 . 0 0} \mathbf{( 4 . 6 2 - 7 0 . 1 4 )}$ \\
\hline Current pesticide use & $0.77(0.16-3.57)$ & - \\
\hline Traps more expensive & $0.86(0.18-4.03)$ & - \\
\hline Current rodent infestation & $0.88(0.16-4.62)$ & - \\
\hline $\begin{array}{l}\text { Would buy trap from } \\
\text { taxi rank }\end{array}$ & $\mathbf{1 1 . 1 7}(\mathbf{2 . 3 4 - 5 3 . 3 2 )}$ & $\mathbf{1 7 . 7 5} \mathbf{( 4 . 2 2 - 7 4 . 5 7 )}$ \\
\hline Gender (male) & $\mathbf{6 . 2 3}(\mathbf{1 . 0 4 - 3 7 . 0 9})$ & $\mathbf{8 . 8 6} \mathbf{( 1 . 7 3 - 4 5 . 1 9 )}$ \\
\hline Had problems with traps & $0.39(0.05-2.80)$ & - \\
\hline Age & $0.98(0.92-1.04)$ & - \\
\hline POR $=$ Prevalence odds ratios. & &
\end{tabular}

strongly associated with the reported intention to use traps (POR 17.8, 95\% CI 4.2 to 74.6). Males were 8.9 times more likely than females (95\% CI 1.7 to 45.2 ) to report the intention to use traps in the future. Pesticide use at the time of follow up was strongly associated with the intention to continue using pesticides in the future (POR 58.2, 95\% CI 19.7 to 172.0) (not shown in Table 2).

From the non-prompted responses, of the total sample, $85 \%(n=148)$ of respondents reported that they liked the traps. Specifically, respondents reported that liked the fact that the traps were efficient at catching rodents $(33.1 \%$, $\mathrm{n}=49)$, that the traps were safer than pesticides $(18.0 \%$, $\mathrm{n}=26)$ and that the rodent carcass was easy to find and remove $(18.0 \%, \mathrm{n}=25)$. This was in contrast to looking for the carcasses, for example in the roof, as was the case with pesticides. Furthermore, $14 \%(n=21)$ reported that they liked the power and look of the trap, 10\% $(\mathrm{n}=15)$ reported that there were fewer rats seen when traps were used and $8 \%(\mathrm{n}=12)$ reported that they were easy to use.

Only 18 respondents indicated that they had a problem when using the traps and from the small sample, most of these were female $(77.8 \%, \mathrm{n}=14)$. Of the 18 respondents who had reported problems with the traps, $50 \%$ reported that they were scared to use the traps or scared that their children might get hurt by them and, $22 \%$ indicated that they did not know how to use the traps. A further $11 \%$ indicated that the trap caught rodents too slowly and two indicated that they had "mechanical" problems (e.g. one person commented that "sometimes the bigger rats will move the traps and you find it somewhere else"). Another respondent noted that "at first everyone was scared of it until our big brother came and did it for us. Now all of us are using it".

\section{Discussion}

The majority of respondents (78.3\%) reported using pesticides at baseline. Although there was a significantly strong association between pesticide use at baseline and follow up, more than half of the people using pesticides at baseline stopped using pesticides at follow up. This demonstrates that many pesticide users were willing to give up their pesticide use and that it was quite rare for non-pesticide users to start using pesticides. Overall, just over a third (34.5\%) of participants reported using pesticides at follow up and even fewer (29.2\%) reported that they intended to use pesticides in the future. Of those that still intended to use pesticides, the majority intended to also use rat traps. This indicates that even when an individual is convinced of the effectiveness of pesticides, they may still be willing to simultaneously try alternatives.

In the baseline survey, only about a quarter $(24.7 \%$, $\mathrm{n}=44$ ) of the respondents had ever used rat traps and less than half of them were using rat traps at the time of the baseline survey $(n=19)$. With the majority of respondents (84.5\%) in this acceptability study reporting intention to use traps in the future, the results indicate a general willingness to change from using street pesticides to rat traps for rodent control.

In order for rat traps to be a viable public health intervention to prevent rodent-borne diseases and pesticide poisonings, acceptability factors need to be taken into account. The factors identified as promoting acceptability were: whether the trap caught rodents, the gender of the user and willingness to purchase a trap from the same informal vendor locations where street pesticides are purchased.

Whether the trap caught rodents or not was strongly associated with trap acceptability. Only $4 \%$ of respondents who used traps did not catch rodents with their trap. This highlights the high levels of rodent infestations, which explains why so many people use toxic pesticides. The perceived trap effectiveness was influenced by the type of trap used. The commonly used and widely accessible traps in most South African supermarkets and hardware stores are wooden traps (Figure 1) that were described by respondents to be ineffective in killing rodents and tended instead to maim them, particularly the large rats found in South Africa. The study traps were designed to be effective in that they are made of a heavy duty plastic, had a fast and sensitive spring action, and a serrated edge (Figure 1). Thus in order for the intervention to be accepted, the product needs to be of a better quality than that which is currently used or available in the most accessible shops, especially in poor urban areas. In addition, qualitative data suggest that being able to easily locate the rodent carcass was viewed as an advantage. The odour of decaying rodent carcasses in inaccessible places is a noted drawback of pesticide use and could be used as a reason to encourage rat trap use instead of pesticides. Thus the traps have multiple benefits.

Males were more likely to indicate that they would use traps in the future. This may reflect societal roles as males may be looked upon as protectors and expected or see it 
as their duty to eradicate larger pests. Since traps require some physical strength to set, this may reinforce the perception that it is a male's responsibility to do so. Of those that had problems, females $(78.9 \%)$ had more problems using the traps than males (21.1\%) some admitting that they were scared to use them as they could hurt them or their children. The use of traps may result in injured fingers; however this is a lesser hazard than pesticide poisoning. The qualitative data did not suggest that any children were harmed by the rat traps. The gender finding suggests that in future interventions, effort should be put into making sure that females are given extra support when shown how to use traps. For example, an informal vendor selling rat traps could demonstrate how to set traps and have a potential customer set it under their supervision, until the potential customer is confident in doing it by him or herself. Women could also be advised on how to use rat traps more safely by putting them in places inaccessible to children or putting the traps out at night only.

The questions asked relating to cost and buying traps were hypothetical as respondents were given the traps for free. The willingness to buy traps at an informal market/ local taxi rank (where street pesticides are sold) was strongly associated with rat trap acceptability. Many people indicated that they were willing to buy traps at informal markets. However, when asked what they were willing to pay for traps, many quoted prices that were much lower than the actual cost of the traps but higher than the current prices for street pesticides. Illegal pesticides are cheap (US\$0.13- US\$0.26) [9]. Traps represent an investment because they are more expensive. However, rat traps can last for several months and can be reused, whereas people need to continually purchase pesticides. The cost-benefit of investing in a trap may thus need to be marketed as a way to promote trap use. Traps could compete with pesticides if the price of traps were subsidized by government, or by the industry whose agricultural pesticides are being used illegally for domestic rodent control. The affordability of traps is an important factor as this may affect the sustainability of its use.

The study had some limitations, particularly regarding the accuracy of information elicited. The data were self-reported and the purpose of the project was known to participants. Their answers could thus have been affected by desirability bias, although fieldworkers were trained to ensure that they did not prompt respondents for answers. Also, the person who was interviewed in the household may not have been responsible for pest control for the family.

\section{Conclusions}

With climate change predicted to increase levels of pest infestations and pesticide use in poor urban communities [37], it is important to promote the use of alternative non-toxic rodent control methods. The sustained use of rat traps in poor communities through an integrated approach to rodent control that involves ministries of health, community members, non-governmental organisations and other relevant stakeholders could assist in decreasing the double health burden caused by exposure to toxic pesticides and rodent-borne diseases. Rodent control with traps needs to occur together with public health measures aimed at alleviating the underlying factors contributing to rodent infestations, for example, through improving sanitation and waste control.

Most important, the study suggests that rat traps are an acceptable alternative as the majority of respondents used the traps to catch rodents while decreasing their reliance on pesticides. These findings could be applicable to other poor communities with rodent infestations and access to cheap street pesticides. There is potential for rat traps to be widely accepted if high quality rat traps could be made available and at the same time the barrier of the high cost of such traps could be overcome.

Studies are needed to determine if sustained trapping in poor urban communities reduces rodent populations and pesticide use over the long-term. As rodent control is an important public health disease prevention measure, there is a need to advocate for the accessibility of rat traps and cost reduction of rat traps in these impoverished urban communities, as well as policies to restrict residential use of hazardous pesticides.

\section{Additional files}

\section{Additional file 1: Follow up questionnaire \\ Additional file 2: Supplementary data. Selected tables not presented} in main article

\section{Abbreviations}

Cl: Confidence Interval; EPA: Environmental Protection Agency; POR: Prevalence Odds Ratio.

\section{Competing interests}

The authors declare that they have no competing interests

\section{Acknowledgements}

The authors would like to thank the respondents and fieldworkers for their time and effort put into answering and conducting both the baseline and follow-up surveys. This article is part of a larger study funded by the South African Medical Research Council and the Danish International Development Agency (DANIDA).

\section{Author details}

${ }^{1}$ School of Public Health and Family Medicine, University of Cape Town, Anzio Rd., Observatory, 7925, Cape Town, South Africa. ${ }^{2}$ Population Health, Health Systems and Innovation, Human Sciences Research Council, Cape Town, South Africa.

\section{Authors' contributions}

$\mathrm{H}$-AR was the principal investigator of the project, conceptualised the project and methods used, developed the protocol, secured funding, supervised data collection and analysis of data and was involved in the research, write up and editing. RE gave input on the statistical analysis, writing and editing. RR analysed the data, did the write up of the article and editing. All authors read and approved the final manuscript. 
Received: 18 January 2012 Accepted: 3 May 2012

Published: 3 May 2012

\section{References}

1. Resnik DB, Roman G: Health, justice and the environment. Bioethics 2007, 4:230-241. doi:10.1111/j.1467-8519.2007.00547.x.

2. Landrigan PJ, Claudio L, Markowitz SB, Berkowitz GS, Brenner BL, Romero H, Wetmur JG, Matte TD, Gore AC, Godbold JH, Wolff MS: Pesticides and inner-city children: Exposures, risks, and prevention. Environ Health Perspect 1999, 3:431-437.

3. Centers for Disease Control and Prevention: Rodents.: Atlanta Georgia, USA 2010 [http://www.cdc.gov/rodents/]

4. Amatre G, Babi N, Enscore RE, Ogen-Odoi A, Atiku LA, Akol A, Gage KL, Eisen RJ: Flea diversity and infestation prevalence on rodents in a plague-endemic region of Uganda. AmJTrop Med Hyg 2009, 81:718-724. doi:10.4269/ ajtmh.2009.09-0104.

5. Graves MH, Janda JM: Rat-bite fever (Streptobacillus moniliformis): a potential emerging disease. Int J Infect Dis 2001, 5:151-155. doi:10.1016/S1201-9712(01) 90090-6.

6. Meerburg BG, Singleton GR, Kijlstra A: Rodent-borne diseases and their risks for public health. Crit Rev Microbio/ 2009, 3:221-270. doi:10.1080/ 10408410902989837

7. Tobin ME, Fall MW: Pest control: Rodents. University of Nebraska: USDA National Wildlife Research Center; 2004.

8. Kirsten F, Maltitz E, Malebana F: Extension of ecologically-based rodent management in South Africa: DFID Crop Protection Programme; United Kingdom 2006, 76-77. [http://www.researchintouse.com/nrk/RIUinfo/outputs/R8441_FTR. pdf].

9. Rother H-A: Falling through the regulatory cracks: Street selling of pesticides and poisoning among urban youth in South Africa. Int J Occup Environ Health 2010, 16:202-213.

10. Rother H-A: Poverty, pests and pesticides sold on South Africa's streets: Implications for women and health. Women Environ 2008, 76/77:36-40. Fall/Winter.

11. Balme KH, Roberts C, Glasstone M, Curling L, Rother HA, London L, Zar H, Mann MD: Pesticide poisonings at a tertiary children's hospital in South Africa: An increasing problem. Clin Toxicol 2010, 9:928-934. doi:10.3109/ 15563650.2010.534482.

12. Caldas E, Rebelo F, Heliodoro V, Magalhaes A, Rebelo R: Poisonings with pesticides in the Federal District of Brazil. Clin Toxicol 2008, 46:1058-1063.

13. Julien R, Levy J, Adamkiewicz G, Hauser R, Spengler J, Canales RA, Hynes HP: Pesticides in urban multi unit dwellings: Hazard identification using classification and regression tree (CART) Analysis. J Air Waste Manag Assoc 2008, 58:1297-1302. doi:10.3155/1047-3289.58.10.1297.

14. Saller J, Reyes P, Maldonado PA, Gibbs SG, Byrd TL: Children's exposures to pesticides use in homes and farms. J Environ Health 2007, 7:27-31.

15. Tagwireyi D, Ball DE, Nchachi CFB: Toxicoepidemiology in Zimbabwe: Pesticide poisoning admissions to major hospitals. Clin Toxicol 2006, 44:59-66. doi:10.1080/15563650500394878.

16. Landrigan PJ, Claudio L, Markowitz SB, Berkowitz GS, Brenner BL, Romero H, Wetmur JG, Matte TD, Gore AC, Godbold JH, Wolff MS: Pesticides and inner-city children: Exposures, risks, and prevention. Environ Health Perspect 1999, 107:431-437.

17. Centers for Disease Control and Prevention: Poisonings associated with illegal use of aldicarb as a rodenticide - New York City, 1994-1997. Morbidity and Mortality Weekly 1997, 41:961-963.

18. Lifshitz M, Shahak E, Bolotin A, Sofer S: Carbamate poisoning in early childhood and in adults. Clin Toxicol 1997, 35:25-27.

19. Tolosana S, Rother H-A, London L: Child's play: Exposure to household pesticide use among children in rural, urban and informal areas of South Africa. S Afr Med J 2009, 99:180-184

20. Guillette LJ: Endocrine disrupting contaminants-beyond the dogma. Environ Health Perspect 2006, 114:9-12. doi:10.1289/ehp.8045.

21. Kofman O, Berger A, Massarwa A, Friedman A, Jaffar AA: Motor inhibition and learning impairments in school-aged children following exposure to organophosphate pesticides in infancy. Pediatr Res 2006, 60:88-92. doi:10.1203/01.pdr.0000219467.47013.35.

22. Pogoda JM, Preston-Martin S: Household pesticides and risk of pediatric brain tumors. Environ Health Perspect 1997, 11:1214-1220.

23. Jensen HK, Konradsen F, Jors E, Petersen JH, Dalsgaard A: Pesticide use and self-reported symptoms of acute pesticide poisoning among aquatic farmers in Phnom Penh, Cambodia. J Toxicol 2011, 639814:1-8. doi:10.1155/2011/639814.

24. Lee WJ, Cha ES, Moon EK: Disease prevalence and mortality among agricultural workers in Korea. J Korean Med Sci 2010, 25:S112-S118. doi:10.3346/jkms.2010.25.S.S112.

25. De Silva HJ, Samarawickrema NA, Wickremasinghe AR: Toxicity due to organophosphorus compounds: What about chronic exposure? Trans $R$ Soc Trop Med Hyg 2006, 100:803-806. doi:10.1016/j.trstmh.2006.05.001.

26. Jors E, Morant RC, Aguilar GC, O Lander F, Bælum J, Konradsen F: Occupational pesticide intoxications among farmers in Bolivia: a crosssectional study. Environ Health 2006, 5:1-9. doi:10.1186/1476-069X-5-10.

27. Kamel F, Hoppin JA: Neurologic dysfunction and disease. Environ Health Perspect 2004, 112:940-958. doi:10.1289/ehp.7135.

28. Perera FP, Rauh V, Tsai WY, Kinney P, Camann D, Barr D, Bernert T, Garfinkel R, Tu YH, Diaz D, Dietrich J, Whyatt RM: Effects of transplacental exposure to environmental pollutants on birth outcomes in a multiethnic population. Environ Health Perspect 2003, 111:201-205. doi:10.1289/ehp.5742.

29. Whyatt RM, Rauh V, Barr DB, Camann DE, Andrews HF, Garfinkel R, Hoepner LA, Diaz D, Dietrich J, Reyes A, Tang D, Kinney PL, Perera FP: Prenatal insecticide exposures and birth weight and length among an urban minority cohort. Environ Health Perspect 2004, 112:1125-1135. doi:10.1289/ehp. 6641.

30. Environmental Protection Agency: EPA Takes Major Actions to Reduce Americans' Risks from Mouse and Rat Poisons/Move will better protect children, pets and wildlife, 2011 [http://yosemite.epa.gov/opa/admpress.nsf].

31. Belmain SR, Meyer AN, Timbrine R, Penicela L: Managing rodent pests in households and food stores through intensive trapping. In Rats, mice and people, Volume 96. Edited by Singleton GR, Hinds LA, Krebs C, Spratt D.: Rodent biology and management. ACIAR Monograph; Canberra, 2003:440-445.

32. National Cancer Institute $\mathrm{NCl}$ : Theory at a glance: A guide for health promotion practice (second edition).: U.S. Department of Health and Human Services; 2005, Washington DC [http://www.cancer.gov/cancertopics/ cancerlibrary/theory.pdf].

33. Rogers EM: Diffusion of Innovations. New York: The Free Press; 1962

34. Rahman SMM, Rahman S: Breast cancer perceptions, knowledge and behavioral practices among women living in a rural community. International Journal of Cancer Prevention 2008, 6:415-425.

35. Palis FG, Singleton $G$, Sumalde $Z$, Hossain M: Social and cultural dimensions of rodent pest management. Integr Zoo 2007, 3:174-183. doi:10.1111/j.1749-4877.2007.00057.x

36. Chaves B, Riley J: Determination of factors influencing integrated pest management adoption in coffee berry borer in Colombian farms. Agric Ecosyst Environ 2001, 87:159-177. doi:10.1016/S0167-8809(01)00276-6.

37. Gratz NG: Urbanization, arthropod and rodent pests and human health: Proceeding of the 3rd International Conference on Human Pests; Prague, Czech Republic, 1999 [http://www.icup.org.uk/reports/ICUP466.pdf].

\section{doi:10.1186/1476-069X-11-32}

Cite this article as: Roomaney et al.: The acceptability of rat trap use over pesticides for rodent control in two poor urban communities in South Africa. Environmental Health 2012 11:32.

\section{Submit your next manuscript to BioMed Central and take full advantage of:}

- Convenient online submission

- Thorough peer review

- No space constraints or color figure charges

- Immediate publication on acceptance

- Inclusion in PubMed, CAS, Scopus and Google Scholar

- Research which is freely available for redistribution 